\title{
Digitalisation strategies in a South African banking context: A consumer services analysis
}

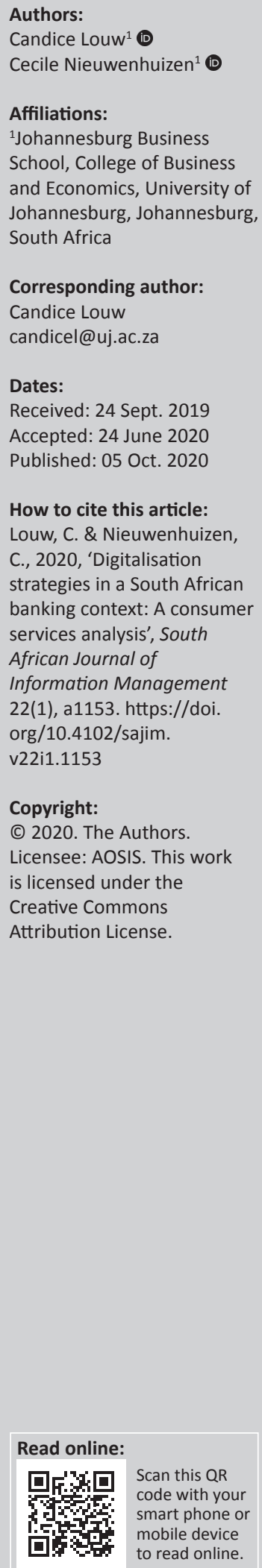

Background: In the advent of the fourth industrial revolution, Internet-only/digital-only banks are offering alternative approaches to facilitating online transactions and banking in the absence of physical branches. As a result, traditional, offline banks may possibly experience increased pressure in growing and retaining their customer base.

Objectives: The objective of this study is to understand the fundamental differences between traditional and digital-only banks' business models and digital user experience strategies from a consumer services perspective. As a result, in this research, we established to what extent traditional South African banks have embraced service digitalisation and compared this to the services offered by South Africa's first digital-only bank (launched in early 2019).

Method: By means of convenience sampling, we selected the five biggest traditional banks and the first digital-only bank in South Africa (as recorded at the start of July 2019) and conducted a comparative analysis of the core digital services that were offered to consumers.

Results: Overall, mobile-optimised services were identified as a key digital business strategy, thereby highlighting the importance of a mobile-first approach not only to traditional and digital-only banking services strategies but also to digital business model formulation in general.

Conclusion: While the overall South African banking landscape and banking user experience may be moving towards digital-first and mobile-first, the need for access to banking technology and services 7 days a week necessitate not only mobile-first, but accessible-foremost (i.e. access to infrastructure that facilitates access to online banking technologies, both remotely and on premise) banking business models.

Keywords: digital banking; digitalisation; online banking; mobile banking; user experience; consumer services.

\section{Introduction and literature review}

With the growth and increased adoption of the Internet and online technologies over the past few decades, many opportunities for business digitalisation and new digital business model formulation have arisen (Louw \& Nieuwenhuizen 2019). As a result, businesses worldwide are being reinvented and reconfigured with the advent of the Fourth Industrial Revolution (4IR), with banks being no exception to the rule.

Banking consumer services (i.e. services that are delivered to consumers through digital channels such as websites, Internet banking portals and smartphone applications [apps]) in particular are becoming increasingly more reliant on technology. There is a chance that banks may miss out on the value benefits as offered by traditional human (in-person) connects, facilitated by the traditional business models that necessitate customers visiting a bank branch (Kulkarni \& Dambe 2019). Moreover, the unique characteristics of digital services imply that there exist different consumer evaluation processes from those used when assessing tangible goods (Hill 1986).

As such, organisations are realising that the intangible aspects of a relationship that are facilitated through digital channels and services are not easily duplicated by competition, thus providing a sustainable competitive advantage (Roberts, Varki \& Brodie 2003). When focussing on banking consumer services in particular, value outcomes (tangible as well as ones perceived by consumers) become key pillars upon which the business subsequently stands (Kulkarni \& Dambe 2019). 
A business model that caters to diverse human characteristics and values (through digital channels) becomes a key factor for consideration during the digitalisation process of a bank's consumer services (Kulkarni \& Dambe 2019).

Based on this observation, it is arguable that digital technologies are fundamentally changing the global banking industry by blurring the traditional lines that define product, market and customer base (Pyun, Scruggs \& Nam 2002), thereby liberating and harmonising financial systems on a global scale (Mercieca, Schaeck \& Wolfe 2007). As a result, when setting banks against a background of far-reaching structural change and technological enhancement, their responses to the changing competitive environment most often include seeking out diversification, vertical product differentiation and consolidation (Goddard et al. 2007).

In certain instances, however, new technologies and services may threaten replacing traditional banks in their entirety. Internet- or digital-only banks offer alternative approaches to online transacting and banking by making services available exclusively through online channels (websites) or by means of smartphone apps, thereby challenging traditional banking business models by eliminating the need to establish and maintain physical bank branches. Technology has fundamentally altered the creation, delivery, reception and utilisation of these financial products (Pyun et al. 2002), with convenience and economic efficiency already having had positive effects on consumers' adoption intention and continuance intention of international digital-only banks (Lee \& Kim 2020).

In response to this, and with the advent of the 4IR, traditional (offline) banks may arguably experience increased pressure in growing and retaining their customer base while also addressing the heterogeneity expected by customers by means of digitalisation of consumer services (Pallant, Sands \& Karpen 2020). As a result, the continuous adoption of innovative offline, online and mobile value-added services is core to ensuring customer satisfaction, retention and arguably business continuity (Goddard et al. 2007).

With the rapid pace of technological evolution, making the correct choice of digital platforms and tools to implement becomes critical to ensuring widespread user adoption, acceptance and overall success (Louw \& Nieuwenhuizen 2019). There is, however, an inherent risk (most notably from a cyber and information security perspective) when adopting new technologies or tools. As first and fast movers accept and manage this risk, more pressure may be placed on competitors to follow suit (Roberts et al. 2003). As more key industry stakeholders begin to adopt similar technology-first initiatives, trends may arise, thereby ultimately defining customer expectation.

Despite the aforementioned perceived risks, digital-only banks challenge the status quo in the traditional banking industry through launching new and more affordable products into the market because of lower running costs achieved by outsourcing operational premises to affiliates (such as supermarkets) with existing infrastructure and a wide reach (Business Tech 2019a; Kulkarni \& Dambe 2019). By leveraging the opportunities of outsourcing major infrastructure in this way, the provision of bank accounts that require very little to no monthly maintenance fees is, in turn, possible. The growth of these unexpected players emerging in the financial services industry has subsequently created a 'marketplace without boundaries' (Camarante \& Brinckmann 2017). This implies that non-traditional players are increasingly exploring new opportunities, enabling them to challenge incumbents and continually changing the state of financial services in South Africa (Camarante \& Brinckmann 2017).

It is thus arguable that traditional banking business models (that predominantly require clients to visit a physical branch) as whole are being challenged; however, because of the very recent (in 2019) introduction of the digital-only banking concept in South Africa, very little to no research literature is available on the topic from a South African perspective.

To address this shortcoming in existing South African research literature, we survey the South African banking landscape and analyse the trends in digital consumer services on offer from a selection of traditional, offline banks. We subsequently compare our findings with the services offered by the first South African digital-only bank launched in 2019, noting the expectations of consumers and the differences in business models from a consumer services perspective (i.e. services that are delivered to consumers through digital channels such as websites, Internet banking portals, smartphone applications, mobile banking and also services that facilitate process digitisation such as point of sale [POS] devices that may be used to process digital payments) across both types of banks.

This research is novel in its kind as the concept of a digitalonly bank in South Africa is still a very recent introduction (launched in 2019). The value of the research stems from the fact that early trend analysis and identification in a South African context, supported by technological advancement, is sure to liberate the digital banking landscape to a further extent, thereby providing guidance and supporting the development of further digital-only banking services and initiatives not only within South Africa (by analysing trends and encouraging further development), but possibly also on a global scale. This may further advance and contribute to the theory on digital business model formulation from a South African perspective.

These observations subsequently support the formulation of our research aim (RA), which was to determine if there were similarities between traditional and digital-only South African banks' digitalisation efforts from a consumer services perspective. This includes services that are delivered to consumers through digital channels such as websites, Internet banking portals, smartphone applications, mobile 
banking and also services that facilitate process digitisation such as POS devices (terminals that may be used to process digital payments).

To address our RA, we identified two research questions (RQs):

- Research question 1 (RQ1) - Which digital consumer services are offered by traditional South African banks?

- Research question 2 (RQ2) - Which digital consumer services are offered by digital-only South African banks?

The rest of the article is organised as follows: We begin with a discussion on the chosen research method and design, followed by a presentation of research results. This is followed by an interpretive discussion section, while the conclusion is found in the last section.

An overview of the chosen research method and design follows next.

\section{Research method and design}

Per analysis of the South African banking industry, it was noted that in February 2019, South Africa recorded 19 registered banks, four mutual banks, four co-operative banks, 15 local branches of foreign banks and 30 foreign banks with approved local representative offices (South African Reserve Bank Prudential Authority 2019). Although there is a strong representation of both locally and internationally owned traditional banks, 2019 saw the country's first fully licensed digital-only bank launched into the market in February (Business Tech 2019a).

By analysing the total population of traditional banks in South Africa, a non-probability sampling method was chosen to select a sample of five traditional banks and one digitalonly bank that were operational in February 2019. By means of convenience sampling, the five biggest 'traditional' banks in South Africa (hereafter collectively referred to as 'traditional banks') were subsequently chosen in February 2019 (Business Tech 2019b), as well as the first digital-only bank in South Africa. Although some of the chosen traditional banks that form part of the sample may be foreign-owned, the focus of this study was on including the banks that are favoured by a majority of South African consumers, regardless of the bank's origin and/or ownership.

Through further qualitative analysis and individual inspection of secondary data, a combination of online and offline sources (including research databases, publications, printed material, bank websites, online resources, digital publications and smartphone application-hosting platforms) were consulted on a first-hand basis to identify the digital consumer services offered by each bank. Data and results obtained for each bank were tabulated, commonalities and differences were identified and the results were consolidated into a single table. From a reliability and validity perspective, it was confirmed that the selected banks and services were still operational and delivered at the end of the second quarter of 2019 (i.e. end of June 2019), thereby justifying their inclusion in the sample.

By means of a comparative analysis, similarities (resulting in trends) and differences (identifying possible opportunities) in digital consumer services offerings were identified, noted and summarised by comparing the traditional banks with each other and also by comparing the traditional banks with the digital-only bank. As a result, the findings from the analysis from the comparative analysis of both traditional banks with traditional banks, and traditional banks with the digital-only bank, were tabulated separately. The presentation and discussion of these results follows in more detail next.

\section{Ethical consideration}

This article followed all ethical standards for research without direct contact with human or animal subjects.

\section{Results}

As traditional banks have been around longer than digital-only banks, the analysis of digital services offered to consumers by traditional banks is discussed firstly.

As web banking technologies are certainly crucial to banks to be found in the digital age, it is imperative to have a web presence (Louw \& Nieuwenhuizen 2020). South African banks have subsequently ensured that they are visible online, with all five banks (100\%) having implemented a website.

With a great variety of different Internet-enabled devices being capable of accessing websites, ensuring that bank websites are optimised for accessibility on any device becomes important (Louw 2017). As such, all five banks have opted for a responsive website design that allows their particular website to adjust to the width of the screen of the device it is being viewed on. This makes it easier to find important information, regardless of whether the website is viewed on a smartphone, tablet or computer screen. Optimising a website's layout to be responsive to the device it is being viewed on can be performed automatically (four out of five banks) or manually (one out of five banks) by the end user (depending on the device they have chosen to view the website on) through selection of on-screen options.

Once a user can find a bank's website, they may also be inclined to conduct their actual banking online. The demand for this is reflected by Internet banking services being offered by all five banks (100\%).

When moving away from web technologies and focussing on mobile and smartphone technologies, banking smartphone applications (apps) for Android and iOS devices are provided by all five banks (100\%). Additionally, three out of five banks provide an app for Windows Phone devices, although three out of five banks also provide an app for BlackBerry devices. At a bare minimum, a smartphone app that is supported by at least two major platforms, most notably Android and iOS, is provided by each bank. 
All five banks (100\%) also offer their smartphone app as a zero-rated data app which means that no data usage costs will be incurred (as agreed upon by Internet service providers and mobile network providers) for end users when making use of the app to conduct their banking (Futter \& Gillwald 2015). This is arguably a major benefit of making use of smartphone apps in an environment where broadband data are still relatively expensive (Geerdts et al. 2016), and this offers further incentive for banks to adopt a mobile-first strategy.

To make use of any of these smartphone apps, however, end users would need to be in possession of a supported smartphone. As smartphones are typically more expensive than feature phones (especially in developing economies such as South Africa) and in certain cases may also be perceived as being more complicated to use (thereby defining an undesirable user experience, i.e. the overall experience of a person using a product and determining how easy or pleasing it is to use) than feature phones, users may choose to not be in possession of a smartphone (Louw \& Von Solms 2018; Louw 2017; User Experience n.d.). This choice thereby excludes these users from making use of the smartphone app features on offer. Fortunately, however, mobile banking via unstructured supplementary service data (USSD) has been adopted by all five banks (100\%). This makes mobile banking possible to those who do not possess a smartphone (and subsequently cannot download a mobile app onto their device), but are in possession of a more basic mobile or feature phone instead (which allows them to access banking services through dialling dedicated mobile banking numbers by means of their device's keypad and interacting with onscreen prompts). This ensures that a wide spectrum of users may benefit from the conveniences offered by South African banks through a mobile phone.

When exploring further opportunities that smartphones have to offer in a traditional South African banking context, POS technologies become of particular interest. A mobile POS system that can connect to a supported smartphone may further open up a world of small business prospects for entrepreneurs. This may not only assist with digitising informal trading, but also enhance an emerging economy by embracing a safer, cashless society. As it currently stands, however, only three out of the five banks (60\%) have this service available. Fortunately, for larger organisations, all banks $(100 \%)$ offer a standard POS system that they may make use of to process payments.

Overall, mobile- or smartphone-first banking does seem to be a strongly pursued component of the digital transformation trend in South African banks. This is evident from Table 1, where seven digitalisation items are identified, six of which are either directly or indirectly optimised for usage with a smartphone. These include a responsive website and Internet banking, a smartphone app, USSD banking, zero-rated smartphone apps and a smartphone-powered POS device.

From the discussion and data presented in Table 1, three major categories of technologies can be identified including:

1. web banking technologies (website, Internet banking)

2. smartphone banking technologies (smartphone applications, mobile or USSD banking, zero-rated data)

3. point of sale banking technologies (smartphone POS and standard POS).

TABLE 1: Digital consumer services of the biggest five South African banks as surveyed during the end of June 2019.

\begin{tabular}{|c|c|c|c|c|c|c|c|}
\hline \multirow[t]{2}{*}{ Bank number } & \multicolumn{2}{|c|}{ Web banking technologies } & \multicolumn{3}{|c|}{ Smartphone banking technologies } & \multicolumn{2}{|c|}{ POS banking technologies } \\
\hline & Website & Internet banking & Smartphone application (app) & Zero-rated app & Mobile banking (USSD) & Smartphone POS & POS \\
\hline \multirow[t]{3}{*}{1} & Yes (responsive) & Yes & Android & Yes & Yes & Yes & Yes \\
\hline & & & iOS & & & & \\
\hline & & & Windows Phone & & & & \\
\hline \multirow[t]{4}{*}{2} & Yes (responsive) & Yes & Android & Yes & Yes & No & Yes \\
\hline & & & iOS & & & & \\
\hline & & & Windows Phone & & & & \\
\hline & & & BlackBerry 10+ & & & & \\
\hline \multirow[t]{4}{*}{3} & Yes (non-responsive) & Yes & Android & Yes & Yes & No & Yes \\
\hline & & & iOS & & & & \\
\hline & & & Windows Phone & & & & \\
\hline & & & Blackberry $10+$ & & & & \\
\hline \multirow[t]{2}{*}{4} & Yes (responsive) & Yes & Android & Yes & Yes & Yes & Yes \\
\hline & & & iOS & & & & \\
\hline \multirow[t]{2}{*}{5} & Yes (responsive) & Yes & Android & Yes & Yes & Yes & Yes \\
\hline & & & iOS & & & & \\
\hline \multirow[t]{4}{*}{ Adoption rate $(\%)$} & 100 & 100 & $\begin{array}{l}100 \\
\text { (across all OSs) }\end{array}$ & 100 & 100 & 60 & 100 \\
\hline & & & $\begin{array}{l}\text { (Android, iOS: } 5 / 5 \\
\text { occurrences }=100 \% \text { adoption) }\end{array}$ & & & & \\
\hline & & & $\begin{array}{l}\text { (BlackBerry: } 3 / 5 \\
\text { occurrences }=60 \% \text { adoption) }\end{array}$ & & & & \\
\hline & & & $\begin{array}{l}\text { (Windows Phone: } 3 / 5 \\
\text { occurrences }=60 \% \text { adoption) }\end{array}$ & & & & \\
\hline
\end{tabular}

POS, point of sale; OSs; operating systems; USSD, unstructured supplementary service data. 
Moreover, from these three major categories that were identified, that is, web banking technologies (website, Internet banking), smartphone banking technologies (smartphone applications, zero-rated data, mobile or USSD banking) and POS banking technologies (smartphone POS and POS), a smartphone-related element or optimisation is present in each. This is summarised in Table 2.

Although not all banks offer all of the listed products and some may only offer a subset thereof, an undeniable mobilefirst trend can be identified in each bank's case. This is further exasperated by the '\#datafree' movement that allows certain apps, including banking apps, to be listed as zerorated (i.e. not incurring data usage and download costs when transacting on the app to make mobile banking more affordable and accessible to all) on most major local network providers (Futter \& Gillwald 2015).

As smartphones are typically more expensive than feature phones and in certain cases may be perceived as being more complicated to use than feature phones (Louw 2017), users may choose to not be in possession of a smartphone. As such, banking through USSD ensures that users with more basic feature phones are also able to benefit from the conveniences offered by the mobile-first banking movement. As previously recorded in other industries, this suggests that local market circumstances - such as Internet penetration and mimicking behaviour - play a major role (Bleyen \& Van Hove 2007).

This observation is specifically applicable in the South African banking context with all (100\%) banks having chosen to support Android and iOS smartphone apps - the two most popular smartphone operating systems (OSs) not only in South Africa and Africa, but also in the world (Statcounter Global Stats 2019). This is an important aspect to take into account when possibly considering expansion into further markets. Mobile-first, localised banking services will arguably thus play an increasingly important role in the consumer banking industry going forward and form an integral part of any bank's overall customer experience.

With a thorough understanding of traditional banks' digital services on offer, we now revisit RQ1 (which digital consumer services are offered by traditional South African banks?) by stating that traditional banks have embraced digital service technologies specifically from a consumer services perspective by delivering a selection of web banking technologies, smartphone banking technologies and POS banking technologies. The majority of these services have notably also been optimised for use with mobile and smartphone devices.
The digital-only bank's consumer services are subsequently summarised in Table 3.

With a better understanding of the digital-only bank's digital services on offer, we now revisit RQ2 (which digital consumer services are offered by digital-only South African banks?) by stating that the first digitalonly bank has embraced digital service technologies specifically from a consumer services perspective by delivering predominantly web banking technologies and smartphone banking technologies.

As a result, we now address the RA (to determine if there were similarities between traditional and digital-only South African banks' digitalisation efforts from a consumer services perspective) by noting that in both cases, web banking technologies and smartphone banking technologies are not only a similarity, but also a priority. Both of these approaches arguably facilitate banking anytime, anywhere. This, in turn, highlights the elements of convenience and economic efficiency that have been found to have positive effects on consumer's adoption intention and continuance intention of digital services (Lee \& Kim 2020) to hold true in a South African context too.

In the case of both the digit-only bank as well as the traditional banks in South Africa, the move to mobile applications to facilitate convenient consumer services delivery is thus undeniable. These results certainly highlight the early trends, arguably also defining minimum requirements for further market liberalisation and possible new market entrants. A discussion on these and other business implications follows in more detail next.

\section{Discussion}

Key findings from this research indicate that at the end of the second quarter of 2019, all participating traditional banks offered users access to the bank's website (responsive design), Internet banking services (via the

TABLE 2: South African banks mobile-first digital consumer services.

\begin{tabular}{llll}
\hline Category & Classification & Components & $\begin{array}{l}\text { Smartphone focussed or } \\
\text { optimised element present? }\end{array}$ \\
\hline 1 & $\begin{array}{l}\text { Web banking } \\
\text { technologies }\end{array}$ & $\begin{array}{l}\text { Website } \\
\text { Internet banking }\end{array}$ & Yes \\
\hline 2 & $\begin{array}{l}\text { Smartphone } \\
\text { banking } \\
\text { technologies }\end{array}$ & $\begin{array}{l}\text { Smartphone } \\
\text { applications } \\
\text { Zero-rated app } \\
\text { Mobile or USSD } \\
\text { banking }\end{array}$ & Yes \\
& & $\begin{array}{l}\text { Smartphone point } \\
\text { of sale }\end{array}$ & Yes \\
& Point of sale & \\
\hline
\end{tabular}

POS, point of sale; USSD, unstructured supplementary service data.

TABLE 3: Digital consumer services of the first digital-only South African bank as surveyed during the end of June 2019.

\begin{tabular}{|c|c|c|c|c|c|c|c|}
\hline \multirow{2}{*}{$\begin{array}{l}\text { Digital-only bank } \\
\text { number }\end{array}$} & \multicolumn{2}{|c|}{ Web banking technologies } & \multicolumn{3}{|c|}{ Smartphone banking technologies } & \multicolumn{2}{|c|}{ POS banking technologies } \\
\hline & Website & Internet banking & Smartphone application (app) & Zero-rated app & Mobile banking (USSD) & Smartphone POS & POS \\
\hline D1 & Yes (responsive) & Yes & Android & Yes & No & No & No \\
\hline Adoption Rate (\%) & 100 & 100 & 100 (Android) & 100 & 0 & 0 & 0 \\
\hline
\end{tabular}

POS, point of sale; USSD, unstructured supplementary service data. 
aforementioned website), access to (at least) an Android and iOS smartphone app, local, zero-rated data rights for these smartphone banking apps, mobile banking via USSD options and POS systems.

A similar approach has been followed by South Africa's first digital-only bank with emphasis (early in the race) being on making access available to the bank's website (responsive design), Internet banking services (via the aforementioned website), access to an Android smartphone app (possibly because of Android currently being the most popular OS worldwide [Statcounter Global Stats 2019]) and local, zero-rated data rights for this smartphone banking app.

By revisiting our RA (to determine if there were similarities between traditional and digital-only South African banks' digitalisation efforts from a consumer services perspective), it is possible to note that in both the cases of the traditional banks and the digital-only bank, mobile-optimised services were identified as a key digital business strategy thereby highlighting the importance of a mobile-first approach to not only banking services, in particular, but also digital business model formulation in general. This can be seen as the primary, practical implication resulting from this study.

This research has arguably thus achieved what was originally aimed for, with the research findings arguably also supporting the earlier discussion which indicated that with the advent of the 4IR, traditional (offline) banks may arguably experience increased pressure in growing and retaining their customer base while also addressing the heterogeneity expected by customers by means of digitalisation of consumer services (Pallant et al. 2020). From a South African banking perspective, however, mobile-optimised services including a responsive website, Internet banking facilities and a smartphone application (for at least Android and iOS devices) are what consumers expect at a minimum.

Despite mobile-optimised services arguably playing a big role in not only digital banking, but also general digital business model formulation going forward, mobile-first initiatives may, however, be perceived differently by different generations of users as follows (Murphy 2018):

- Generation Z, or the digital age, are digital natives that usually prefer interactions through mobile.

- Generation X, or the optimist, are ready to learn how to use and interact through digital and mobile channels.

- Baby boomers, or pragmatists, are open to using digital channels and interacting through them to see if it is an improved experience.

- Senior users (older generations), often referred to as the digital doubters, prefer more traditional banking interactions (such as going to a physical branch), but will try digital for certain activities if it proves to be helpful and easy enough.

As such, banks that are pursuing major digital- and mobilefirst transformations should ensure that the needs of the full spectrum of customers are taken into account and consider delivering level-appropriate training and awareness to not intimidate or overwhelm non-technical customers such as seniors or digital doubters (Louw 2017). Although digitalisation might not necessarily prove to be a perfect solution for all generations of customers (especially seniors or digital doubters), mobile- or smartphone-first banking does seem to be a strongly pursued component of the digital transformation trend in South African banks as a whole.

As mentioned previously, however, technology (such as smartphones, tablets and phablets) to access these services are typically more expensive and may be perceived as intimidating or overwhelming from a user experience perspective (Louw \& Von Solms 2018; Louw 2017). Users who are not in possession of such devices may therefore be excluded from making use of digital banking features and services.

Dedicated access to infrastructure (such as a branch, technology devices, etc.) that allows access to digital banking facilities should thus not be completely disregarded in the move to digital. This has been acknowledged by a traditional South African bank that has experienced the most growth over the past 5 years - not only is it the youngest entrant to the market and offers fewer services than what its traditional bank competitors offer, but it also provides consumers access to selected dedicated branches 7 days a week as opposed to the 6 days a week that most competitors offer (bank number 2 in Table 1). Similarly, although the digital-only bank does not have any physical bank branches, access to digital banking technology infrastructure is available 7 days a week at selected affiliate supermarkets' premises.

In both the cases of the new entrant traditional bank and the digital-only bank, fewer services are offered than those of some competitors (see bank 2 in Table 1 and bank D1 in Table 2), but prolonged hours of access to infrastructure that encourages the use of the respective banks' banking services may (speculatively) be providing a competitive edge.

These findings are, however, limited to only a select few South African banks and may not be representative of the South African banking landscape in its entirety - a limitation of this research. Despite this limitation, our research findings arguably imply that mobile-first, localised banking services are playing an increasingly important role in digital consumer banking.

Furthermore, while the overall South African banking landscape may be moving towards digital- and mobile-first, the need for physical access to technology and services, whether because of circumstance (lack of funds or resources) or by choice (technology avoidance), may necessitate not only mobile-first, but also accessible-foremost banking business models (i.e. 7 days a week, on-premises access to 
infrastructure and support that facilitates access to online banking technologies).

\section{Conclusion}

With the advent of the 4IR, many industries, including the banking industry, consider pursuing digitalisation across their business models and services to remain relevant. Traditional South African banks have acknowledged this fact by offering consumers access to their bank's website (responsive design), Internet banking services (via the aforementioned website), access to (at least) an Android and iOS smartphone app, local, zero-rated data rights for these smartphone banking apps, mobile banking via USSD options and POS systems.

South Africa's first digital-only bank has followed suit and provided consumers access to the bank's website (responsive design), Internet banking services (via the aforementioned website), access to an Android smartphone app and local, zero-rated data rights for users making use of this smartphone banking app.

Although digitalisation might not necessarily prove to be a perfect solution for certain generations of customers (often referred to as digital doubters), mobile- or smartphone-first banking does seem to be a strongly pursued component of the digital transformation trend in South African banks. This arguably implies that a mobile-first user experience design across all digital channels is key to remain relevant with the advent of the 4IR. Furthermore, while the overall South African banking landscape may be moving towards digital- and mobile-first, the need for physical access to technology and services, whether because of circumstance (lack of funds or resources) or by choice (technology avoidance), may necessitate not only digital- and mobile-first, but accessible-foremost banking business models (i.e. 7 days a week, on-premises access to infrastructure and support that facilitates access to online banking technologies).

Despite the research being limited to only a select few South African banks and not necessarily being representative of the South African banking landscape in its entirety, the value of the research stems from the fact that early trend analysis and identification is sure to liberate the digital banking landscape to a further extent, thereby supporting the development of more digital-only services and digital-related entrepreneurial initiatives on a broader scale. This research has contributed to understanding the trends in South African digital banking, specifically from a consumer services perspective.

Future work could include focussing on analysing the entire South African banking population (and not just a sample) to provide a more holistic view of trends and expectations across all traditional and digital-only banks that operate in the country. This may be followed by conducting similar studies for international banks, thereby offering an opportunity to identify global digital banking trends.

\section{Acknowledgements}

The authors would like to thank Brenda Lotriet Louw for proofreading this article.

\section{Competing interests}

The authors declare that they have no financial or personal relationships that may have inappropriately influenced them in writing this article.

\section{Authors' contributions}

All authors contributed equally to this work.

\section{Funding information}

This research received no specific grant from any funding agency in the public, commercial or not-for-profit sectors.

\section{Data availability statement}

The authors confirm that the data supporting the findings of this study are available within the article.

\section{Disclaimer}

The views and opinions expressed in this article are those of the authors and do not necessarily reflect the official policy or position of any affiliated agency of the authors.

\section{References}

Bleyen, V. \& Van Hove, L., 2007, 'Western European newspapers and their online revenue models: An overview', First Monday, The Peer-Reviewed Journal on the Internet 12(12), 1-13. https://doi.org/10.5210/fm.v12i12.2014

Business Tech, 2019a, These are the banks South Africans are most satisfied with viewed 06 September 2019, from https://businesstech.co.za/news/banking/303 548/these-are-the-banks-south-africans-are-most-satisfied-with/.

Business Tech, 2019b, Battle of the banks: South Africa's big 5 banks compared, viewed 08 September 2019, from https://businesstech.co.za/news/banking/339 319/battle-of-the-banks-south-africas-big-5-banks-compared/.

Camarante, J. \& Brinckmann, S., 2017, A marketplace without boundaries. The future of banking: A South African perspective, viewed 26 August 2019, from https:// www.pwc.co.za/en/assets/pdf/strategyand-future-of-banking.pdf.

Futter, A. \& Gillwald, A., 2015, Zero-rated internet services: What is to be done? viewed 25 May 2020, from https://researchictafrica.net/2016/01/25/zero-ratedinternet-services-what-is-to-be-done/.

Geerdts, C., Gillwald, A., Calandro, E., Chair, C., Moyo, M. \& Rademan, B., 2016 Developing smart public Wi-Fi in South Africa, viewed 06 September 2019, from https://www.researchictafrica.net/publications/Other publications/2016 Public Wi-Fi_Policy_Paper_-_Developing_Smart_Public_Wi-Fi_in_South_Africa.pdf.

Goddard, J., Molyneux, P., Wilson, J.O.S. \& Tavakoli, M., 2007, 'European banking: An overview', Journal of Banking \& Finance 31(7), 1911-1935. https://doi. org/10.1016/j.jbankfin.2007.01.002

Hill, D.J., 1986, 'Satisfaction and consumer services', in R.J. Lutz (ed.), Advances in consumer research, vol. 13, no. 1, pp. 311-315, Association for Consumer Research, Provo, UT.

Kulkarni, A. \& Dambe, S., 2019, 'Innovating Digital Consumer Services in Wealth Management Ecosystem an Anthropomorphic Approach', in M. Tuba, S. Akashe \& A. Joshi (eds.), Information and Communication Technology for Sustainable Development. Advances in Intelligent Systems and Computing, vol. 933 pp. 268-277, Springer Nature, Singapore, viewed 28 August 2019, from https:// doi.org/10.1007/978-981-13-7166-0_24

Lee, J. \& Kim, H., 2020, 'Determinants of adoption and continuance intentions toward Internet-only banks', International Journal of Bank Marketing 38(4). https://doi. org/10.1108/IJBM-07-2019-0269

Louw, C., 2017, 'Towards a smartphone application user security competency evolution model', Doctoral thesis, University of Johannesburg Library and Information Centre, Theses and dissertations, viewed 12 Augustus 2020, from hdl. handle.net/10210/261505. 
Louw, C. \& Nieuwenhuizen, C., 2019, 'Online, community-driven E-commerce platforms and the rise of lifestyle commerce: A conceptual study', Seventh annual platforms and the rise of lifestyle commerce: A conceptual study', Seventh annual winter global $2584-6302$

Louw, C. \& Nieuwenhuizen, C., 2020, 'Digitalization strategies for SMEs: A cost vs. skill approach for website development', African Journal of Science, Technology, Skill approach for website development', African Journal of Science, Technology,
Innovation and Development 12(2), 195-202. https://doi.org/10.1080/204213 Innovation and Deve

Louw, C. \& Von Solms, B., 2018, 'Smartphone usage and security maturity: A South African student evaluation', in A. Jøsang (ed.), ECCWS 2018, $17^{\text {th }}$ European conference on cyber warfare and security, 28-29 June 2018, pp. 268-277, Oslo.

Mercieca, S., Schaeck, K. \& Wolfe, S., 2007, 'Small European banks: Benefits from diversification?', Journal of Banking \& Finance 31(7), 1975-1998. https://doi. org/10.1016/j.jbankfin.2007.01.004

Murphy, C., 2018, 5 ways banks can create a digital mindset, viewed 03 August 2019, from https://www.mobilepaymentstoday.com/blogs/5-ways-banks-can-create-adigital-mindset/.
Pallant, J., Sands, S. \& Karpen, I., 2020, 'Product customization: A profile of consumer demand', Journal of Retailing and Consumer Services 54(2020), 102030. https:// doi.org/10.1016/j.jretconser.2019.102030

Pyun, C.S., Scruggs, L. \& Nam, K., 2002, 'Internet banking in the U.S., Japan and Europe', Multinational Business Review 10(2), 73-81.

Roberts, K., Varki, S. \& Brodie, R., 2003, 'Measuring the quality of relationships in consumer services: An empirical study', European Journal of Marketing 37(1/2) 169-196. https://doi.org/10.1108/03090560310454037

South African Reserve Bank Prudential Authority, 2019, Selected South African banking sector trends February 2019, viewed 28 August 2019, from https://www. resbank.co.za/Lists/News\%20and\%20Publications/Attachments/9136/02\%20 February\%202019.pdf.

Statcounter Global Stats, 2019, Mobile operating system market share worldwide 2018 , viewed 25 August 2019, from https://gs.statcounter.com/os-market-share/ mobile/worldwide/\#monthly-201801-201812.

User Experience, n.d., Lexico powered by OXFORD dictionary, viewed 25 May 2020, from https://www.lexico.com/definition/user_experience. 